José Carlos Pereira ${ }^{1}$

\title{
Procedimentos para lidar com o tabu da morte
}

\author{
Procedures for dealing with the taboo of death
}

\begin{abstract}
The more death is studied, the more it remains a mystery. Dealing with death is no easy matter and for that reason it is so frightening. All the fears of human beings are fundamentally related to the fear of death. This is because it is a mystery about which we know little or nothing, although it is natural to die. In view of this, religions give this topic a primary focus. Therefore, in this article an attempt is made to deal with the taboo surrounding death and reflect on issues associated with it. These themes are present in people's lives, especially when they have the experience of losing someone in their family or circle of friends. Among these subjects, the aspects of the Anointing of the Sick, the Funeral Mass, the Seventh Day Mass and the tradition of praying for the dead are all touched upon. These are all themes that help to deal with the taboo of death or losing a loved one.
\end{abstract}

Key words Illness, Death, Mourning, Taboo, Religion, Rituals
Resumo A morte, por mais estudada que seja, continua sendo um mistério. Lidar com ela não é algo nada fácil e por essa razão ela assusta tanto. Todos os medos do ser humano estão, no fundo, relacionados com o da morte. Tudo isso por ela ser um mistério do qual pouco ou nada sabemos, embora seja natural. À vista disso, as religiões dão a este tema o seu principal enfoque. Assim sendo, procuro neste artigo tratar o tabu da morte, refletindo temas relacionados a ele. Temas que estão presentes na vida das pessoas, sobretudo quando passam pela experiência da perda de alguém do seu círculo familiar ou de amizade. Dentre eles, abordo a Unção dos Enfermos, as Exéquias, a Missa do Sétimo Dia e a tradição de rezar pelos mortos. Temas que ajudam a lidar com o tabu da morte ou a perda de um ente querido.

Palavras-chave Doença, Morte, Luto, Tabu, Religião, Rituais
${ }^{1}$ Núcleo de Pesquisa Religião e Sociedade, PUC/ SP. R. Monte Alegre 984, Perdizes. 05.014-901 São Paulo SP.

cpzeca@uol.com.br 


\section{Introdução}

Lidar com a morte é algo desafiador. Por mais que se busquem formas de amenizar a dor deste fato, ela continua assustadora e é um dos objetos principais de medo do ser humano. Assim sendo, as religiões adotam procedimentos que têm como finalidade, amenizar o sofrimento e ajudar as pessoas a lidarem melhor com ela.

Nesse sentido, tratarei de alguns procedimentos usados pela Igreja Católica, dentre eles, a Unção dos Enfermos, as Exéquias, a Missa do Sétimo Dia e a tradição de se rezar pelos mortos. Darei destaque para a Missa do Sétimo Dia, por se tratar de uma tradição presente no imaginário religioso e na prática incentivada pela Igreja.

Antes de entrar no tema, achei importante abordar alguns elementos conceituais do campo da antropologia, bem como temas relativos à morte, como, por exemplo, o sacramento da unção como preparação para a morte; os ritos de exéquias realizados antes do sepultamento; e o costume ou o hábito de se rezar pelos mortos. Estes temas são fundamentais para a compreensão e o deslindamento do tabu da morte, pois de certa forma, são procedimentos para lidar com ela.

\section{A unção dos enfermos}

\section{como preparação para a morte}

A primeira descrição da função de unção dos enfermos no Catecismo da Igreja Católica é extraída da Constituição Dogmática Lumen Gentium $^{1}$ em que é conferida à Igreja, através de seu poder simbólico, personificado nos representantes oficiais, padres e bispos, a incumbência, por intermédio do ritual da unção, de entregar o doente aos cuidados de Deus, cuja finalidade é aliviar e salvar. Compreendemos que o conceito de alivio e salvação pode ser entendido também como o passamento do doente, ou seja, a morte, cuja salvação corresponde à inclusão no reino celeste. Afirma o texto: "pela sagrada Unção dos Enfermos e pela oração dos presbíteros, a Igreja toda entrega os doentes aos cuidados do Senhor sofredor e glorificado, para que os alivie e salve"2.

A "enfermidade se torna caminho de conversão" 2 e, à vista disso, é um meio de arregimentar os fiéis, enfermos ou não, mantendo-os assim sob seu domínio. Visto por este prisma, a unção dos enfermos parece fazer apologia do sofrimento, mas sua função, na verdade, é outra: aliviar a dor. Para isso, se recorre aos rituais, cuja incumbência é exorcizar o infortúnio. Como o ritual da unção conecta o corpo do enfermo com seu mundo social e espiritual, contém um veio de informações sobre seu ethos e sua visão de mundo, no sentido dado por Geertz ${ }^{3}$, provocando, com isso, resultados que, em muitos casos, respondem aos objetivos do ritual proposto. Da mesma forma, como sugere Malinowski ${ }^{4}$, sobre o rito e a fórmula na arte da magia e o poder da fé, o ritual da unção dos enfermos funciona também num plano psicológico, proporcionando um marco de referência coerente para os aspectos desorientadores da vida humana, como a enfermidade, o perigo de morte e, consequentemente, as mudanças vitais que a atual condição provoca no indivíduo, dando-lhe um sentimento de controle sobre tais fatos perturbadores e ameaçadores. A unção dos enfermos não cura o doente, mas elimina o sentimento de impotência e desespero associado à enfermidade e isso pode, de fato, agilizar o restabelecimento da saúde, ou ajudar na maneira de se lidar com a enfermidade. Esta é a faceta do poder simbólico desse sinal sagrado.

\section{Especificidade do poder simbólico da unção}

Afinal, de onde advém a especificidade do poder simbólico do sacramento da unção? Quem ilumina a reflexão sobre a gênese de semelhante categoria de poder é Geertz ${ }^{3}$, quando analisa os símbolos religiosos e suas correlações ontológicas, cosmológicas, estéticas e morais, mostrando que a peculiaridade do poder dos símbolos sagrados, dos quais faz parte a unção, "provém de sua suposta capacidade de identificar o fato com o valor no seu nível mais fundamental, de dar um sentido normativo abrangente àquilo que, de outra forma, seria apenas real". Desse modo, os católicos acreditam que o óleo da unção é um sinal sagrado produzido e administrado pelos representantes de Deus por meio de rituais que fazem parte de sua tradição religiosa e de sua crença, ou, no dizer de Geertz $z^{3}$, “o poder desse símbolo repousa claramente em sua abrangência, em sua produtividade ao ordenar a experiência". A ideia de um óleo sagrado, quando empregado numa situação de enfermidade ou de debilidade física, readquire novos significados.

Conforme sentenciou Durkheim, "uma experiência, repetida muitas vezes, demonstrou que, em princípio, os ritos produzem o efeito que se espera deles e que constitui a sua razão de ser"s. Com efeito, a unção dos enfermos, parte integrante dos ritos sacramentais da Igreja Católica, é uma prática que se repete ao longo da tradição com o propósito de diminuir o sofrimento e li- 
vrar a pessoa enferma da condenação eterna. Por causa disso, acredita-se que tal rito produza o efeito desejado que é o conforto espiritual, a confiança no acolhimento divino e até mesmo a cura, senão do corpo, pelo menos da alma, constituindo, assim, a razão de ser do que aqui convencionamos chamar de inclusão no transcendente. Embora alguns hesitem em receber a unção dos enfermos e seus ritos, por acreditar que, com isso, estejam à beira da morte, quando aceitos, "são celebrados com segurança, no gozo antecipado do feliz acontecimento que preparam e anunciam"

Por estar comprometido com uma condição de enfermidade comumente grave, e, portanto, com a possibilidade da morte, os ritos da unção dos enfermos são, ordinariamente, realizados na agonia e na aflição. Por isso, servimo-nos da denominação proposta por Durkheim ${ }^{5}$ e vamos analisá-los como parte de um conjunto de ritos classificados como piaculares, que são os ritos das exéquias, da missa de sétimo dia e do luto. De modo geral, denominam-se piaculares as cerimônias tristes, cuja função é opor-se a calamidades ou, simplesmente, relembrá-las e deplorálas. Mas não é somente isso que está envolto neste tipo de celebração, pois também tem a função de afastar "todo infortúnio, tudo o que existe de mau agouro, tudo o que inspira sentimentos de angústia ou de temor" ${ }^{\text {. }}$. Na concepção de Durkheim, a enfermidade necessita de piaculum e, por isso, a cerimônia de unção dos enfermos pode ser classificada como piacular, assim como são os ritos fúnebres.

Entretanto, é necessário distinguir os diferentes ritos que envolvem aflição e desgosto. Vale insistir que a unção dos enfermos constitui um sacramento e os demais são ritos fúnebres. Em função disso, trataremos primeiro do rito da unção dos enfermos, frequentemente praticado a partir do momento em que a morte parece iminente, mas ainda não ocorreu. Segundo o Catecismo da Igreja ${ }^{2}$, este "é um sacramento que existe entre os sete sacramentos especialmente destinado a reconfortar aqueles que são provados pela enfermidade", reconfortando mais ainda os seus familiares, embora desperte nas pessoas certo temor e tremor ${ }^{6}$ por se tratar de algo que toca a grandiosidade do mistério da morte. Tal sentimento deriva da própria concepção que representa esse sacramento quanto à hora de recebê-lo. Isso reforça, na crença católica, não apenas o recebimento da unção como iminência da morte, mas também a de que, se a morte chegar sem que o doente a tenha recebido, poderão acontecer penas para sua alma. Daí as infindáveis ele- gias e ritos mortuários, como a encomendação do corpo e as recomendações da alma, as missas pela alma do falecido e outros tantos atos funéreos como forma de compensação do não recebimento do último sacramento, objetivando encaminhar, para junto de Deus, a alma daquele que faleceu.

\section{A unção como preparação para a inclusão no transcendente}

A inclusão na esfera do transcendente, não obstante o que já elucidamos, não deixa de ter, no entendimento comum, representação do mundo factual, do meio social que o enfermo e seus familiares idealizam a partir de referências concretas, embora muitas vezes, ideais. Esse espaço familiar, efetivo ou apenas desejável, é transportado para a dimensão metafísica, formulando-se assim, uma imagem hipotética do transcendente a partir de conceitos do espaço físico. De fato, tudo é representação de uma realidade social reproduzida para o além, criando espaços extrafísicos, de acordo com as concepções humanas.

As reflexões acima deixaram claro que a função da unção era também a de proteção e que a mesma funcionava como um substituto da confissão. Além disso, trazia, no seu conjunto, o poder de cura: "o sacramento perdoava os pecados pendentes do enfermo, culpas esquecidas durante a confissão, mas podia também resultar em sua recuperação física quando assim convém ao bem da alma"'7. Ademais, tinha a função, que perdura ainda hoje, de eliminação das dívidas com Deus, purificando o nome nos registros divinos e garantindo, novamente, crédito junto d'Ele. Deste modo, a alma poderia passar para o outro lado sem maiores percalços.

\section{A função curativa da unção}

O sacramento da unção é apresentado no seu ritual como o sacramento da cura, ou como sinal da atividade sanante de Deus para com a pessoa enferma. O sentido de cura dado a este sacramento tem diversos alcances, sendo, todavia, temporal e escatológico. A primeira parte do ritual reforça essa ideia com fundamentos teológicos e eclesiológicos extraídos das Sagradas Escrituras. Adverte que o sacramento da unção faz parte dos sete sacramentos e que, por ser bíblico, não é invenção da Igreja, é sim algo instituído por Jesus Cristo para curar a pessoa por inteiro, como sugerido em várias passagens bíblicas, como, por exemplo, no evangelho de $\operatorname{Marcos}^{8}$, 
em que os doentes eram curados depois de serem ungidos com óleo. A epístola de Tiago ${ }^{9}$ recomenda que, se alguém está doente, mande chamar o presbítero da igreja, para que ore sobre ele, ungindo-o com óleo em nome do Senhor. Segundo tais textos, a oração e a unção salvam o doente, além de perdoar seus pecados. Dessa forma, o rito reafirma sua origem divina e enfatiza o poder sobrenatural que exerce sobre os fiéis ao longo da história da Igreja, seja para curar a alma, a mente ou mesmo o corpo.

O Concílio Vaticano II, segundo Azevedo ${ }^{10}$, "destinado a lhe tirar o sentido agourento tão temido", procurou dar nova conotação a esse sacramento, reorientando sua nomenclatura, que, de extrema unção, passou a ser chamado de unção dos enfermos. Mesmo assim, não aboliu as decisões dos demais Concílios nem apagou do imaginário religioso a característica de extrema unção.

Como todo ritual religioso, esse também manifesta o seu caráter funcionalista em relação ao social, proporcionando o equilíbrio. Além do mais, o costume de ungir a pessoa na enfermidade é parte da cultura católica, sendo, portanto, uma resposta da religião às necessidades fundamentais ou naturais como a doença e a morte. Se por um lado a unção é vista como um rito temido e, portanto, terrível, por outro "podemos ver nela a sublime loucura da esperança"4. Isso porque ela tem o poder simbólico de reduzir o medo, funcionando como elemento catártico das circunstâncias de infortúnio. Nos momentos críticos da existência, como nos casos de doenças graves, quando a pessoa corre risco de perder seu autocontrole e sua integridade mental, os ritos da unção dos enfermos permitem escapes para tais situações e impasses, conduzindo-os ao domínio do sobrenatural.

Afinal, existem outros ritos ligados ao sacramento da unção dos enfermos que, embora não sejam sacramentos, estão muito próximos deles, por serem considerados ritos de exorcismo do corpo e da alma, com características sociais que contribuem para afugentar o medo do passamento e fortalecer os grupos sociais na hora da dor causada pela enfermidade ou pela perda. São eles: o viático, as exéquias ou a encomendação da alma, a missa de sétimo dia e o luto.

\section{Exéquias e demais ritos fúnebres}

Falar das exéquias é entrar ainda mais no âmbito dos ritos fúnebres, nas ritualizações por ocasião da morte e nos procedimentos para li- dar com a morte que expressam ação social desencadeada pelo defunto. É importante tratá-los, porque os ritos fúnebres assinalam os mais comoventes costumes da tradição católica, configurados nos diversos tipos de comportamento entre os vivos, ditados pelo episódio da morte. Essa confirmação se dá não apenas no domínio do social, a que muitos insistem em reduzi-lo, mas também numa outra perspectiva, a do 'outro mundo', o do transcendente, outrora também constatada por Malinowski ${ }^{4}$, como algo que transcende o social. A partir da perspectiva da morte, esse autor afirma que "a religião não é idêntica à Sociedade ou ao Social, nem podemos ficar satisfeitos com o vago indício de que se prende unicamente à vida, pois a morte mostra-nos talvez a panorâmica mais vasta sobre o outro mundo". Desse modo, a morte e sua circunscrição, como as cerimônias propiciatórias e consagratórias, isto é, as exéquias, o velório, o sepultamento, o luto, e, sobretudo, a Missa do sétimo dia, mobilizam pessoas, estimulam ações grupais que são fomentadas por esse momento de "crise suprema e final da vida que é a morte"4, ou seja, são ocasiões em que as representações sociais se revestem da maior importância.

Classificamos, em primeira instância, essa modalidade de ritos como cerimônias piaculares, ou seja, celebrações feitas nos momentos de infelicidade, de desdita, como são, de fato, as celebrações motivadas pelo evento da morte. Como sugere Durkheim ${ }^{5}$, são cerimônias "tristes que visam a opor-se a uma calamidade ou, simplesmente, relembrá-la e deplorá-la”. Elas envolvem, pela emoção e comoção, grande número de pessoas que agem, na ocasião social da morte, levadas pelo comportamento das outras. Assim, é necessário analisar alguns destes principais rituais tidos como fúnebres e as experiências que suscitam. Refiro-me ao velório e às exéquias ou encomendação das almas. Começo pelo velório, privilegiando-o como espaço de representações coletivas no intento de lidar com a morte.

\section{O velório}

Velório é o ato de velar um morto. Um evento coletivo no qual as pessoas permanecem junto ao defunto exposto, durante as horas que precedem seu enterro ou cremação. O velório é o espaço ao qual afluem ações em que podemos reconhecer a existência de uma estrutura social da comunidade católica. É uma oportunidade em que assomam representações coletivas ou sociais em torno do evento da morte e suas significações 
que apontam para aspectos relevantes da estrutura social. Não importando o local onde acorre $\mathrm{o}$ ato de velar o corpo - porque este se transforma em espaço sagrado a partir da chegada do féretro - nele as pessoas estão ligadas entre si "por uma série definida de relações sociais num todo integrado"11. Portanto, essa cerimônia, embora seja um evento periódico, é parte do conjunto da vida social e contribui para manter a continuidade estrutural da sociedade.

Durkheim $^{5}$ afirma com isso, que "o estado afetivo no qual o grupo se encontra reflete as circunstâncias que atravessa”. Há, portanto, um efeito contagiante, pois, "não somente os próximos mais diretamente atingidos trazem para a assembleia a sua dor pessoal, mas a sociedade exerce sobre seus membros uma pressão moral para que coloque seus sentimentos em harmonia com a situação".

De acordo com Radcliffe-Brown" ${ }^{12}$, "a função de determinado costume social é a contribuição que este oferece à vida social total como funcionamento do sistema social total". Desse modo, um velório em que muitos pranteiam, figura não apenas a importância do falecido e da família dentro de um sistema social, mas certa unidade, à qual Radcliffe-Brown chamou unidade funcional. Sua função é promover um grau suficiente de harmonia, apaziguando ânimos mais exaltados e possíveis conflitos provenientes de diversas situações que possam emergir nestes espaços, como afirma Balandier ${ }^{11}$ sobre a função do rito: "por meio do rito, os conflitos, as desorganizações e os males são temporariamente transformados; o rito não age nem como um meio de repressão, nem como um exutório; capta as energias que se desprendem dessas situações para converter positivamente, faz do que é provocador de confrontos, de ferida social e de degradação individual, um fator de reconstrução e de coesão".

Mauss $^{13}$ fala em sua nota sobre as lágrimas, enviada a G. Dumas (1920) da "extrema generalidade desse emprego obrigatório e moral das lágrimas" nos ritos funerários e mostra que elas também "servem, em particular, como meio de saudação". Ou seja, a lágrima auxilia na acolhida e no envio do morto, simbolizando receptividade e, ao mesmo tempo, um tipo de identificação que beira o parentesco entre os que estão no espaço sagrado onde ele é velado. Esse autor afirma ser essa uma maneira de cantar o luto e a morte para injuriar, maldizer e encantar o inimigo causador da morte.

Enfim, as lágrimas servem também para aliviar a dureza do aniquilamento e apaziguar as rivalidades ou desentendimentos entre os membros da família, aproximando-os através do choro. Nesse contexto, podemos tratá-la como recurso inerente de conciliação funcional do complexo social que se estabelece em torno do evento da morte, o qual Radcliffe-Brown ${ }^{12}$ definiu "como condição pela qual todas as partes do sistema social atuam juntas com suficiente grau de harmonia ou consistência interna, isto é, sem ocasionar conflitos persistentes que nem podem ser solucionados nem controlados". Mormente, tal ritual funciona como mecanismo de recolocação da vida social no curso da sua normalidade interrompida pela morte.

\section{As exéquias como procedimento para exorcizar o tabu da morte}

O ritual das exéquias não é sacramento, podendo, portanto, ser conduzido por uma pessoa que não tenha recebido o sacramento da ordem. Mesmo assim, ele é uma celebração litúrgica contando, portanto, com a orientação e o aval da Igreja. Em muitos lugares, a presença do padre no velório, por tudo que ele representa, é solicitada pela família, mesmo que um ministro leigo já tenha feito um ritual similar.

Os funerais são, pois, ritos que confirmam o passamento e consolam os que ficam, conferindo esperança. É à vista disso que tal cerimônia é chamada também de "celebração da esperança". Porém, o que se espera com ela? Entre outras coisas, que, por meio deste ritual de encomendação da alma à Deus, que ela, de fato, seja recebida no Reino dos Céus. Essa característica inclusiva das exéquias, como rito de passagem, esperança e consolo, encontra-se, à sua maneira, fundamentada e recomendada no Código de Direito Canônico, que confirma: "as exéquias eclesiásticas, com as quais a Igreja suplica para os defuntos o auxílio espiritual, honra seus corpos e ao mesmo tempo dá aos vivos o consolo da esperança, sejam celebradas de acordo com as leis litúrgicas"14.

Segundo Mircea Eliade ${ }^{15}$, "para certos povos, só o sepultamento ritual confirma a morte: aquele que não é enterrado segundo o costume não está morto. Além disso, a morte de uma pessoa só é reconhecida como válida depois da realização das cerimônias funerárias" e do sepultamento. No catolicismo, logo após a confirmação do falecimento e da liberação médica do corpo, ocorre a cerimônia fúnebre, conhecida como velório, que é o ritual de preparação para o sepultamento. Quando se aproxima o momento do enterro, 
sucede, então, o ritual das exéquias, popularmente conhecido como encomendação da alma. Azevedo ${ }^{10}$ chamou esse momento de "ritos de sacralização da passagem, em que o corpo do defunto é posto na terra como semente que ressurgirá no dia do julgamento final".

$\mathrm{O}$ rito das exéquias, de acordo com Radcliffe-Brown ${ }^{12}$, são desdobramentos da vida social e, por isso, examiná-lo num todo integrado de relações, atividades e interações sociais, seja de indivíduos ou de grupos, se faz necessário para entendermos o funcionamento da estrutura social. Dessa forma, os rituais da morte, como no caso, as exéquias, são parte da estrutura social, e contribuem para a manutenção da continuidade estrutural através da cerimônia fúnebre.

\section{A missa do sétimo dia como memória e tradição}

O que é a tradição e como ela determina os costumes? A tradição é o ato ou efeito de se transmitir, transferir algo a determinada pessoa, grupo ou sociedade, de forma espontânea e natural, de modo que tal ato ou efeito passe espontaneamente de geração em geração, sem que seja questionado. Existem várias formas de algo se transformar em tradição, dentre elas, a comunicação oral de fatos, lendas, ritos, usos e costumes, bem como a reprodução prática desses fatos. Tais costumes acabam por se transformar num conjunto de valores que são assimilados, transmitidos e vividos sem que haja interesse em buscar explicações racionais para os mesmos. Isso ocorre principalmente com a herança cultural religiosa, com crenças que foram legadas ou com qualquer outro costume relacionado à religião. É um pouco isso que ocorre com a missa do sétimo dia. Ela se configura, em primeiro lugar, como tradição e costume, e muitas pessoas não estão preocupadas em saber o porquê desse ritual. Numa família católica, praticante ou não, sempre que ocorre a morte de um membro, procura-se a igreja para marcar a missa do sétimo dia. Na maioria dos casos não precisa haver orientação para isso porque é algo que ocorre ao espírito como resultado de experiências já vividas com outros familiares e fica como recordação, memória ou eco da prática religiosa que está envolta em muitas crenças, como, por exemplo, a de que se não houver missa do sétimo dia a alma do falecido não entra no céu.

Desse modo, a tradição é um território da imaginação, mas sua presença tem consequências muito significativas na vida social. Quando dizemos que algo é tradicional, estamos assegurando que ele é valioso, que fala eloquentemente acerca de nós, da nossa cultura e que devemos prestar mais atenção nesse fato e respeitá-lo. É o que ocorre com a missa do sétimo dia. Ela é um elemento valioso porque faz parte da nossa cultura católica, e permanece no imaginário religioso do povo brasileiro.

\section{O significado da missa do sétimo dia}

A missa do sétimo dia é um ritual de estreita ligação com o luto, porque uma de suas funções é, precisamente, a de delimitar o período de resguardo depois do ocorrido fatídico, em que sobrevém uma espécie de transformação na vida da família. Dessa forma, é importante não desvinculá-la do conjunto que envolve o estado de luto. A missa, como parte integrante dessa condição talvez essencial na tradição católica, consiste, portanto, num marco simbólico divisório entre o episódio da morte e o retorno da normalidade no cotidiano da vida dos familiares.

A missa do sétimo dia se tornou um momento forte de solidariedade social, ocasião em que os parentes e amigos mais achegados se reúnem para fazer a entrega definitiva daquela pessoa que foi chamada deste mundo para as mãos de Deus. Portanto, afora a devoção e a crença na acolhida divina, forma-se um círculo de relações sociais em volta desse acontecimento.

Sabe-se que a missa de sétimo dia é uma tradição que se formou na história da Igreja, com a intenção de sufragar a alma da pessoa falecida, cuja origem descende de antigos ritos mortuários. A celebração da missa por ocasião da morte ocorria, a princípio, diante do cadáver da pessoa e era chamada de missa de corpo presente. Até certo tempo, essa foi uma prática comum, principalmente nos vilarejos e cidades do interior, em que a escassez de padre não era tanta. Antes que a missa de corpo presente se tornasse inviável, já se havia instalado no imaginário popular católico, a obrigação de mandar rezar missa pelos mortos.

Na Bíblia, a simbologia dos números atribui aos sete e seus correlatos, os significados de "totalidade, plenitude, completação ou perfeição"16. A referência ao número sete e seus derivados (setecentos, setenta, sétimo), aparece na Bíblia, em diversos livros, somando um total de 662 vezes, segundo o dicionário de Concordância Bíblica ${ }^{17}$. Destarte, diversos relatos, como por exemplo, a narração do livro do Gênesis ${ }^{18}$, mostra que Deus levou sete dias para criar o mundo e, quanto ter- 
minou, vendo que era bom, perfeito, descansou. Portanto, o paralelismo desta passagem com a missa do sétimo dia simboliza que aquela pessoa, após cumprir sua missão nesta terra, poderá agora também descansar.

Observamos que várias referências bíblicas citadas estão relacionadas diretamente com as cerimônias fúnebres e com os tipos de comportamentos presentes nessa categoria de evento, como, por exemplo, o ato de chorar, jejuar e fazer penitências, além de lamentações e reações agressivas, o que se observa ainda hoje. Sobre relatos bíblicos de rituais da morte, o livro do Gênesis descreve que quando morreu Jacó, um dos patriarcas do Antigo Testamento, "fizeram um funeral grandioso e solene e José guardou por seu pai um luto por sete dias"19. O primeiro livro de Samuel afirma que, por ocasião da morte do rei Saul, seus comparsas guerreiros queimaram seu corpo e depois enterraram os ossos debaixo de uma árvore fazendo um jejum de sete $\operatorname{dias}^{20}$. Outras duas passagens bíblicas que referem à morte e seus sete dias posteriores estão nos livros de Judite e no Eclesiástico. O primeiro afirma que, quando morreu Judite, a heroína do povo hebreu, os israelitas fizeram luto por sete $\operatorname{dias}^{21}$ e o livro do Eclesiástico afirma que "o luto pelo morto dura sete dias" ${ }^{22}$. Dessa maneira, ganha respaldo bíblico a crença de que é necessário ficar de luto durante sete dias para eliminar as interferências da morte na vida dos familiares e, com isso, diluir a dor. A devoção católica convencionou encerrar esse ciclo com a referida cerimônia, chamada de missa do sétimo dia.

Assim, o costume ou a devoção de se rezar pelos mortos serve como conforto espiritual, um refrigério para a alma daqueles que estão oran$\mathrm{do}^{23}$. Embora não saibamos como são as coisas na eternidade, a não ser pelas indicações bíblicas, vale reafirmar que nunca é demais rezar pelos mortos, não importando se a Missa é do terceiro, do sétimo ou do trigésimo dia. O que vale é a intenção. Isso porque toda intenção de oração é uma manifestação da fé. Quem ora por quem já morreu está demonstrando amor, está dando provas da sua esperança na eternidade. Apesar do desconhecimento do que ocorre após a morte, quem reza pelos mortos demonstra fé tanto nesta vida quanto naquela que se acredita começar depois da morte. Podemos dizer que, ao rezar pelos mortos, estamos manifestando aquilo que professamos quando rezamos o Credo, ou seja, que cremos na comunhão dos santos, na remissão dos pecados, na ressurreição da carne e na vida eterna.
Se observarmos a história da Igreja, vamos encontrar num passado não muito distante, o costume de se pedir missa no terceiro dia de falecimento. Depois vemos outros costumes, que perduram até hoje, como estamos vendo, que é a Missa do Sétimo dia, e também do trigésimo dia, muito em voga na maioria das regiões do Brasil. Podemos, então, perguntar: E por que missa de terceiro dia, como era comum no passado, e missa do sétimo e do trigésimo dia, como acontece hoje? É porque determinados tempos se tornam mais propícios para se orar e se alcançar o favor de Deus. Principalmente se nesses tempos estamos numa situação de maior vulnerabilidade, como ocorre quando a morte abate um membro de nossa família. Deus, que sempre vem em socorro dos necessitados, conhece, nessas circunstâncias, a nossa carência e necessidade. Além disso, há um conjunto de significado que ajudam a reforçar o sentido da Missa nessas ocasiões, como, por exemplo, a do terceiro dia, que lembra que Jesus ressuscitou ao terceiro dia.

\section{A tradição de se rezar pelos mortos}

Não há muitas informações disponíveis sobre a tradição de se rezar pelos mortos, ou pedir missa pela sua alma sete dias depois da morte. Busquei boa parte das referências nos livros de história da Igreja, nas publicações das áreas de Sociologia, Antropologia e Ciências da Religião. Algumas foram obtidas no âmbito da teologia bíblica, fornecidas pelos que estão diretamente envolvidos com essa tradição, os padres, principalmente os padres exegetas. Mesmo assim, nenhum deles soube me informar, com exatidão, o porquê dessa prática. Cruzei as informações obtidas com os gerenciadores do sagrado, com as dos fiéis católicos e as de outros informantes e cheguei à seguinte conclusão: não há uma fundamentação histórica consistente e o embasamento doutrinário para a Missa do sétimo dia é escasso. Sabe-se que é uma tradição que se formou na história da Igreja, com a intenção de sufragar a alma da pessoa falecida, cuja origem descende antigos ritos mortuários e o costume de se celebrar missa por ocasião da morte, a princípio, rezada diante do cadáver e chamada missa de corpo presente. Esta era uma prática comum, principalmente nos vilarejos e cidades do interior do Brasil, em que a escassez de padre não era tanta. Antes que a missa de corpo presente, por razões pastorais se tornasse inviável, já se havia instalado no imaginário popular católico a obrigação de mandar rezar missa pelos mortos, como encon- 
tramos em alguns relatos antigos. Não obstante a devoção popular, de cunho mágico, que se formou em torno desta categoria de evento fúnebre que é a missa do sétimo dia, vale lembrar que, embora exígua, tem certa fundamentação teológica e respaldo bíblico. Tal simbologia contribuiu para intensificar o ritual e tudo aquilo que se engendrou à sua volta e justifica a ação.

Recorro aqui aos primórdios deste tipo de culto fúnebre, que deu origem ao dia de finados, que na atualidade se celebra em dois de novembro. É a partir do século I da era cristã que se tem registro de que os cristãos rezam pelos mortos ou lhes prestam algum tipo de culto religioso, como visitas às catacumbas ou aos túmulos dos mártires.

No século IV já se encontra a memória dos mortos na celebração da missa. Nesse período ainda não se tem claro se essa memória era celebrada no sétimo dia, mas sabe-se que os mortos eram lembrados dentro da celebração eucarística. Até então não havia um dia específico para rezar pelos mortos, como há hoje. Esse dia começou a ser definido a partir do século V, quando a igreja passa a dedicar um dia por ano para rezar por todos os falecidos pelos quais ninguém rezava de forma oficial, social ou religiosa - exceto pelos mártires, como vimos acima - afora os familiares do falecido. A partir do século XI, com os Papas Silvestre II (999-1003), João XVIII (10041009) e Leão IX (1049-1054) passa a existir a obrigatoriedade de se dedicar um dia por ano aos mortos. Porém, mesmo com tal obrigatoriedade, não havia sido ainda instituído um dia específico, como temos hoje. Esse dia variava de acordo com a época.

A partir do século XIII, o dia anual de oração pelos mortos passou a ser 2 de novembro. Essa data foi proposital pelo fato de ela suceder outra data muito importante do calendário católico, o dia de Todos os Santos, $1^{\circ}$ de novembro. Este dia representava a celebração de todos os que morreram em estado de graça, embora não canonizados. Assim, pessoas comuns, ente queridos, já recebiam, de certa forma, um dia de oração. Essa data celebrativa cumpria a função que o dia de finados tem hoje.

O dia de rezar pelos mortos, conhecido como dia de finados, diferentemente do que ocorria no dia de todos os santos, passou a ser aquele em que se celebra para todos os que morreram, indistintamente, e não apenas para os que são lembrados na oração do dia de todos os santos. Desde o início da instituição desta data, era recomendado que se acendesse uma vela no cemité- rio para simbolizar a vida eterna do falecido. Daí o costume que perdura até hoje entre os cristãos católicos de se acender velas no cemitério no dia de finados.

Vale então lembrar que o culto aos mortos é muito antigo e não é uma prática que se restringe apenas ao catolicismo que, comparado a outras religiões da antiguidade, não tem tanto tempo de existência. $\mathrm{O}$ culto aos mortos foi uma prática fundamental de quase todas as religiões antigas, pois esteve inicialmente ligado aos cultos agrários e da fertilidade. Acreditavam os mais antigos que, como as sementes, os mortos eram enterrados com vistas à ressurreição, ou seja, a um novo nascimento. Há, ainda hoje, certa similaridade com essa crença antiga, pois, embora a doutrina seja outra, também se acredita que a morte seja uma passagem para a vida eterna. Sabe-se que os que morreram não estão no cemitério, exceto seus restos mortais, mas que sua alma está junto a Deus, na eternidade. No caso dos ritos fúnebres de algumas religiões da antiguidade, a ideia central da festa dos mortos era a mesma dos ritos agrários e da fecundidade: o retorno à vida que deve surgir de algo oculto e misterioso. Desse modo, o primitivo dia de finados celebrado nas religiões da antiguidade era festejado com banquetes e orgias perto dos túmulos, costume disseminado em várias civilizações da antiguidade e que algumas religiões, de forma mais discreta, ainda preservam, levando ao cemitério, no dia de finados, iguarias e outros alimentos que são deixados sobre o túmulo, numa oferenda aos mortos.

A crença na vida eterna diminui o pesar da morte. Tanto é que nas primeiras comunidades cristãs o dia da morte era chamado de dies natalis, ou seja, dia de nascimento ou renascimento para a vida eterna. Veremos mais adiante que essa é uma das justificativas para o costume de se rezar por ocasião da data do falecimento. É como se a pessoa estivesse aniversariando. Nas primeiras comunidades cristãs a crença na ressurreição era tão firme que o passamento de um ente querido não era motivo para as pessoas ficarem consternadas ou abatidas por muito tempo, mesmo que a separação causasse dor intensa, como continua causando em todos nós, ainda hoje. A certeza da vida eterna era mais forte do que o sofrimento e a dor pelo vazio experimentado com a sua morte. Havia uma esperança intensa, porque se tinha a confiança de que a pessoa falecida estaria viva junto de Deus, porque havia mergulhado na Ressurreição de Cristo e alcançado a comunhão dos santos, junto com o Pai. Isso não 
quer dizer que hoje não se creia, mas a forma como a morte era concebida tinha um significado que ajudava a pessoa a elaborar esse acontecimento de modo que o sofrimento não se tornasse tão intenso. A festa e a alegria davam lugar aos ritos fúnebres e à tristeza.

É importante destacar também algumas diferenças e similaridades entre os ritos fúnebres dos primeiros cristãos e dos pagãos da época e os ritos que temos hoje por ocasião da morte. Enquanto que para os primeiros cristãos e para os cristãos de hoje, a morte era e continua sendo o início de uma vida junto a Deus, motivo de esperança (e, para os primeiros cristãos, até de alegria), para os pagãos ela configurava o início de uma viagem para a escuridão. Daí o sentimento de angústia e sofrimento que imperava entre os mesmos por ocasião da morte. Os pagãos, na ocasião da morte de um ente querido, tinham um tipo de prática que, a princípio, se assemelhava a uma festa, porém, não tinha nada de festivo, era a manifestação de uma preocupação com o morto, baseada em parâmetros deste mundo. Eles tinham o costume de deixar sobre o local do sepultamento, como provisões para a viagem neste túnel de escuridão, alimentos e objetos que supostamente os mortos iriam necessitar. Era costume também entre esses povos, preparar uma festa, um banquete, para recordar os mortos. Nesses banquetes havia um lugar reservado para eles: um banquete de oferenda, visando a suprir supostas necessidades daqueles que agora viveriam nesse tempo de escuridão e privações. Esses banquetes eram realizados em ocasiões específicas: no terceiro, sétimo e trigésimo dia. Encontramos nisso certa similaridade com o costume católico de mandar rezar missas também nessas ocasiões. Porém, sabemos que o significado é outro, embora não deixa de haver certo paralelismo.

\section{O luto e as relações sociais que envolvem a morte}

Luto significa o período de intenso sentimento de tristeza por motivo da morte de alguém, durante o qual devem manifestar-se certos sinais que identifiquem a pessoa enlutada. O sinal mais conhecido é a roupa preta, hoje praticamente em desuso. Algumas pessoas ainda costumam usar alguma peça ou tarja preta no conjunto da vestimenta durante esse período, porém de forma discreta. Os rituais fúnebres marcam o período de luto. Ao realizar o rito da missa do sétimo dia, por exemplo, a obrigação do luto se completa, embora o sentimento pela perda não desapareça de forma mágica, levando, dependendo do caso, a meses e até anos para ser assimilado.

O processo ritual de assimilação, ou como sugere Durkheim ${ }^{5}$, de expiação, faz com que o luto seja um típico exemplo de rito piacular, porque nesse período pós-morte a família precisa de tempo para diluir o sofrimento. Neste tempo, acontecem os rituais religiosos, como a missa do sétimo dia, mas também a do trigésimo e a de um ano do falecimento, e também outras situações e práticas mais prolongadas de expiação da morte, como já citado. Embora a prática do luto ainda seja comum e necessária, não encontramos aqueles sinais exteriores de antanho que caracterizavam o luto com suficiente representatividade, como apontou Azevedo ${ }^{10}$ : "para as mulheres, a roupa preta ou roxa e a combinação desses tons com o branco, às vezes em forma de véu velando o rosto, a encobrir a fisionomia abatida e contraída, não maquiada; para os homens, o fumo no braço direito ou na lapela, consistindo numa faixa negra sobre a roupa escura, cinza ou branca". Hoje, o luto é vivido de forma pouco expressiva, discreta, sem alardes e que só é descoberta quando investigada na proximidade e particularidade de cada caso. Tudo isso porque a morte, nos dias atuais, "é empurrada mais e mais para os bastidores da vida social" 24 . Fhilippe Ariès chegou a alertar para o desaparecimento do luto nas sociedades modernas e afirmou que hoje "só se tem direito a chorar quando ninguém vê nem escuta: o luto solitário e envergonhado é o único recurso" 25 . Concordamos com o autor quanto ao desaparecimento dos símbolos exteriores, mas não com a eliminação do processo de elaboração da morte. Vimos que esse tempo se resignifica e se adapta de acordo com a época e a cultura, mas continua a existir como prática inerente à existência humana. Atualmente, para detectá-lo, é preciso certo tempo de convivência com a família e de contato direto com o campo e o objeto pesquisados. Tudo isso porque o luto dos tempos atuais limita-se "a certos momentos, como os das missas ou cultos memoriais"10. Para Azevedo, mais que o luto, "persiste e assume destaque maior o anúncio de óbito e o convite para uma das reuniões religiosas e de solidariedade"10.

Durkheim $^{5}$ demonstrou que em ocasião de enfraquecimento pela perda, "toda comunhão das consciências, sob qualquer espécie que se faça, realça a vitalidade social". As cerimônias proporcionam, portanto, um motivo de aproximação, levando em conta o estado afetivo do grupo familiar e sua debilidade, como elementos facilita- 
dores do acercamento. O grupo que perdeu um membro sente a impressão de abatimento e é nisso que se encontra, segundo Durkheim, a origem do luto, cuja função é levar as pessoas a se recomporem da perda e fortalecê-las.

Não obstante o que foi visto até agora, o luto e seus rituais, na religião católica, são uma espécie de negação da morte, ou procedimentos para lidar com ela. Configuram uma recusa do aniquilamento, cujo recurso simbólico é acreditar na sua ultrapassagem, a ressurreição, ou, dependendo da crença, em outras modalidades de ressurgimento. É isso que torna o luto uma coisa paradoxal, porque, ao mesmo tempo em que se chora a morte, se busca o consolo na sua própria negação. A crença no ressurgimento neutraliza, pouco a pouco, os reais significados da morte. Portanto, a morte é paradoxal porque o indivíduo tem consciência de que está vivendo uma perda real quando ela ocorre, mas a religião o faz crer no seu contrário, ou seja, de que ela seja apenas uma passagem. Isso ajuda a superar traumas, confirmando o que sugere Morin ${ }^{26}$, que é ver a morte como uma forma de renascimento ou como a sobrevivência do duplo. Assim sendo, acreditar na ressurreição como ressurgimento da pessoa, é, na verdade, negar a morte. De acordo com Durkheim", as pessoas "saem do luto, e saem dele graças a ele mesmo". Portanto, pensar a morte como uma passagem, como uma etapa, significa negá-la como fim implacável da vida.

Afirma Morin ${ }^{26}$ que é a consciência da morte que leva o homem a criar ritos funerais cujo objetivo é exorcizar a própria morte e suas consequências. Isso faz com que a morte seja superada, levando, assim, as pessoas a se comportarem de forma a recusar o desaparecimento do outro, que se exprime, segundo esse autor, "desde a préhistória, nos mitos e ritos da sobrevivência do duplo (fantasma) ou nos do renascimento num ser novo", ou, em outras palavras, na própria ressurreição, conforme prega a doutrina religio- sa católica. Durkheim ${ }^{5}$ considera que é para poder explicar o luto que prolongaram a existência da alma para além do túmulo. Trata-se, segundo ele, de mais um exemplo de como os ritos reagem às crenças.

\section{Considerações finais}

Quero partilhar nessas considerações finais o que ocorreu com a maioria das pessoas com quem tive a oportunidade de acompanhar durante os sete primeiros dias que sucederam a morte de alguém da sua família. Período marcado por um abalo emocional muito intenso. Foi constatado que elas viveram um estado social que chamamos de "estado de suspensão", ou seja, a vivência de um estágio separado da vida cotidiana. Nos sete primeiros dias a pessoa viveu em função do ocorrido, desconectada das atividades do dia a dia, embora esforçando-se para que a vida voltasse à normalidade. A isso chamamos "processo de elaboração da morte e vivência intensa do luto", processo inevitável, mas necessário, quase um ritual, em que a pessoa é colocada no limite de suas resistências emocionais. É esse aspecto que faz da morte um dos ritos de passagem mais evidentes do decurso da vida. Para Arnold Van Gennep ${ }^{27}$, esse "é um estado de margem para os sobreviventes, no qual entram mediante ritos de separação e do qual saem por ritos de reintegração na sociedade geral". Nesse período, a família não consegue ainda elaborar completamente o trágico sucedido e, portanto, a vida social fica desviada da normalidade. Dessa maneira, a missa do sétimo dia e os demais procedimentos que vimos acima, têm a função de incorporá-la ou, como sugere Van Gennep ${ }^{27}$, reintegrá-la em um novo estado, encerrando, assim, o período simbólico do luto. Boa parte das pessoas consegue, depois de tais procedimentos, lidar com a separação causada pela morte, de uma maneira mais confiante. 


\section{Referências}

1. Documentos do Vaticano. Lumen Gentium . Encíclica do Concílio Vaticano II sobre a Igreja. [página na Internet]. [acessado 2013 jul 16]. Disponível em: http://www.vatican.va/archive/hist_councils/ii_ vatican_council/documents/vat-ii_const_19641121 _lumen-gentium_en.html

2. CaIC. Catecismo da Igreja Católica. Petrópolis: Vozes; 1993.

3. Geertz C. A interpretação das culturas. Rio de Janeiro: LTC; 1989.

4. Malinowski B. Magia, ciência e religião. Lisboa: Edições 70; 1984.

5. Durkheim E. As formas elementares de vida religiosa. São Paulo: Paulinas; 1989.

6. Kierkegaard S. Temor e tremor. São Paulo: Abril Cultural; 1979. (Coleção Os Pensadores)

7. Reis JJ. A morte é uma festa. Ritos fúnebres e revolta popular no Brasil do século XIX. São Paulo: Companhia das Letras; 1995.

8. Bíblia Sagrada. Edição Pastoral. 25a Edição. São Paulo: Paulus; 1998. Marcos 6:13.

9. Bíblia Sagrada. Edição Pastoral. 25ª Edição. São Paulo: Paulus; 1998.Tiago 5:14-15.

10. Azevedo T. Ciclo da vida: ritos e mitos. São Paulo: Ática; 1987.

11. Balandier G. A desordem. Elogio do movimento. Rio de Janeiro: Bertrand Brasil; 1997.

12. Radcliffe-Brown AR. Estrutura e função na sociedade primitiva. Petrópolis: Vozes; 1973.

13. Mauss M. Ensaio de sociologia. 2a Edição. São Paulo: Perspectiva; 2001.

14. Conferência Nacional dos Bispos do Brasil. Código de Direito Canônico. $2^{\text {a }}$ Edição. São Paulo: Loyola; 1987.

15. Eliade M. O sagrado e o profano: a essência das religiões. São Paulo: Martins Fontes; 1996.
16. Mackenzie JL. Dicionário Bíblico. 2a Edição. São Paulo: Paulinas; 1983.

17. Sociedade Bíblica do Brasil. Concordância Bíblica. Brasília, DF: [S.1.]; 1975.

18. Bíblia Sagrada. Edição Pastoral. 25a Edição. São Paulo: Paulus;1998. Gênesis 2:2.

19. Bíblia Sagrada. Edição Pastoral. 25a Edição. São Paulo: Paulus;1998. Gênesis 50:10.

20. Bíblia Sagrada. Edição Pastoral. 25a Edição. São Paulo: Paulus;1998. 1Samuel 31:13

21. Bíblia Sagrada. Edição Pastoral. 25a Edição. São Paulo: Paulus;1998. Judite 16:24.

22. Bíblia Sagrada. Edição Pastoral. 25a Edição. São Paulo: Paulus;1998. Eclesiástico 22:11.

23. Bíblia Sagrada. Edição Pastoral. 25a Edição. São Paulo: Paulus; 1998. Salmo 23;22:3.

24. Norbert E. A solidão dos moribundos, seguida de envelhecer e morrer. Rio de Janeiro: Jorge Zahar Editor; 2001.

25. Ariès P. O homem perante a morte II. Lisboa: Publicações Europa-América; 1977.

26. Morin E. O método 5. A humanidade da humanidade. A identidade humana. 2a Edição. Porto Alegre: Sulina; 2003.

27. Van Gennep A. Os ritos de passagem: estudos sistemáticos. Petrópolis: Vozes; 1978.

Artigo apresentado em 05/04/2013

Aprovado em 22/05/2013

Versão final apresentada em 02/06/2013 